\title{
Demokratický právní stát tesaný do pískovce
}

\section{Democratic State Governed by the Rule of Law Carved into Sandstone}

\author{
Onď̌ej Preuss ${ }^{*}$
}

\begin{abstract}
Abstrakt
Clánek usiluje o zpréblednèni některých základních pojmu ústavni teorie. Konkrétně jde zejména o pojmy materiálního jádra či obniska ústavy, neżmènitelných č „věcných" ustanoveni a podstatných náležitostí demokratického právního státu.

Článek vychází z. nejnovèjsich poznnatkè české ústavni teorie.

Podle názoru autora článku jsou výše uvedené pojmy svou povahou odlišné a nelze je uživat pro označení

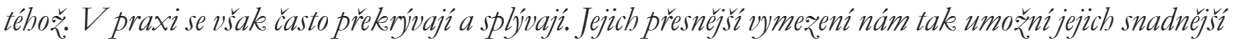
praktické uřití.
\end{abstract}

\section{Klíčová slova}

Ústavni teorie; materiální jádro ústavy; obnisko ústavy; nezฺmènitelná ustanovení ústavy; podstatné náležitosti demokratickébo právního státu.

\begin{abstract}
The Article "Democratic state governed by the rule of law carved into sandstone" has a simple, but ambitious goal. It is a clarifying our thinking about the basic concepts of constitutional law and of constitutional theory. Specifically, these particular terms of the substantive core of the Constitution or an unchangeable or ,eternal" provisions and essential requirements for a democratic state governed by the rule of law.

The Article refers to recent works of $C_{\text {zech }}$ constitutional theory.

According to the conclusions of the author, we could and should define several separate notions (categories), although in practice they can coincide and overlap. It also allows us to easily apply basic constitutional- theoretical postulates in practice.
\end{abstract}

\section{Keywords}

Constitutional Theory; Substantive Core of the Constitution; Unchangeable Provisions of the Constitution; Democratic State Governed by the Rule of Law.

Piskovec je měkeký a dobre opracovatelný prírodni kámen. Z dîvodu menši soudr:̌nosti jsou piskovce obecnè snadno náchylné ke zuětráváni a degradaci vlivem povètrnosti.

\footnotetext{
JUDr. Ondřej Preuss, Ph.D., Katedra ústavního práva, Právnická fakulta, Univerzita Karlova v Praze / Department of Constitutional Law, Faculty of Law, Charles University, Prague, Czech Republic / E-mail: preuss@prf.cuni.cz
} 


\section{Úvod}

Tento článek má jednoduchý, i když poměrně ctižádostivý cíl. Jde o zpřehlednění našeho uvažování o základních pojmech ústavního práva či chcete-li ústavní teorie. Konkrétně jde zejména o pojmy materiálního jádra či ohniska ústavy, nezměnitelných či „věčných“ ustanovení a podstatných náležitostí demokratického právního státu.

Navazuji zde na dvě recentní práce české ústavní teorie, na Materiální obnisko ústavy: věčný limit evropské integrace? Pavla Molka z roku $2014^{1}$ a Podstatné nále žitosti demokratického právniho státu Maxima Tomoszka z roku $2016^{2}$.

Pavel Molek svou práci publikoval s ambicí zpochybnit synonymnost pojmů materiálního ohniska a nezměnitelných náležitostí ústav. ${ }^{3}$ Ve skutečnosti se však knihou line dělení na tři kategorie: materiální ohnisko, nezměnitelná ustanovení a „společné ohnisko“ všech evropských ústav. Ty můžeme pojímat jako jakousi absolutní hodnotovou překážku neomezenosti moci.

Ač jde o přístup poměrně radikální, předložené argumenty svědčí jeho opodstatněnosti a užitečnosti, minimálně co se týče prvních dvou pojmů.

Narážíme zde však velmi těsně i na pojem podstatných náležitostí demokratického právního státu, který užívá česká Ústava ${ }^{4}$ (dále jen „Ústava“) ve svém čl. 9. odst. 2 a který je často považován za synonymní k pojmu materiálního jádra ústavy. Tomuto pojmu a související problematice se zevrubně věnuje Maxim Tomoszek.

Podle něj není demokratický právní stát jen sloučení principů demokracie a právního státu. Je založen na materiálním právním státu. ${ }^{5}$ Lze identifikovat určité prvky (náležitosti), které společně tvoří demokratický právní stát, a ty lze rozdělit na podstatné (esenciálnî) a ostatní. Úplné a konečné vymezení pojmu demokratického právního státu a jeho podstatných náležitostí však s ohledem na přístup Ústavního soudu a dikci Ústavy nelze podle Tomoszka učinit. Materiální pojetí se mưže vyvíjet. ${ }^{6}$

Jak tedy alespoň jasněji vymezit hranice takto neurčitých pojmů? Jejich aplikace má přeci zcela konkrétní důsledky.

Dle závěrů autora tohoto článku je potřeba vymezit ještě více kategorií a ty poměrně jasně oddělit, ač v praxi můžou splývat a překrývat se. To nám umožní i jednodušeji aplikovat základní ústavně-teoretické postuláty v praxi.

1 MOLEK, Pavel. Materiální ohnisko ústavy: vě́ný limit evropské integrace?. 1. vyd. Brno: Masarykova univerzita, 2014.

2 TOMOSZEK, Maxim. Podstatné náleờitosti demokratického práuního státu. 1. vyd. Praha: Leges, 2016.

3 MOLEK, 2014, op.cit, s.12.

4 Zákon č. 1/1993 Sb., Ústava České republiky, ve znění pozdějších předpisů. In: ASPI [právní informační systém]. Wolters Kluwer ČR [cit. 13. 6. 2016].

5 TOMOSZEK, 2016, op.cit, s. 12.

6 TOMOSZEK, 2016, op.cit, s. 56. 
Konkrétně jde o tyto pojmy:

a) Materiální jádro či ohnisko ústavy

b) Nezměnitelná ustanovení ústavy (klausule věčnosti)

c) Demokratický stát - jeho základy

d) Demokratický právní stát a jeho podstatné náležitosti

e) Hodnotová překážka neomezenosti moci

Jednotlivé kategorie a důvod pro jejich odlišení budou postupně vymezeny. Je totiž chybné, že český Ústavní soud kromě „podstatných náležitostíc také v zásadě promiskue užívá pojem materiálního jádra či ohniska ústavy a nezměnitelných ustanovení a přesně se nevyjadřuje ani k dalším z uvedených pojmů. ${ }^{7}$ Tyto pojmy nemohou obecně splývat, i když konkrétně v České republice se v něčem prakticky překrývají díky dikci čl. 9 odst. 2 Ústavy.

\section{$1 \quad$ Materiální jádro ústavy a ústavní identita}

Nauka ústavního práva často chápe materiální jádro, tvrdé jádro či ohnisko ústavy jako soubor hodnot, které danou ústavu (či státní zrrízenî) charakterizuji1. ${ }^{8}$

Pavel Molek k tomu uvádí, že materiální jádro či obnisko označnje spíse ty normy, které určuji samotné qáklady ústavního usporádání, definuji tedy danou ústavu v tom smyslu, že pokud by se na nich nèco żmènilo, šlo by o zcela jönou üstavu, šlo by až o zničeni č odstranèni stávajici ústavy. Splynutí obou pojmü, tedy konstrukce nezménitelných nále žitostí ústavy tak, aby odpovidaly jejímu materiálnímu jádru, je pak ideálem, kterébo nebývá dosaženo.

$\mathrm{S}$ touto kategorií by se tedy mělo pracovat velmi restriktivně a to ze dvou podstatných důvodů. Za prvé nejsou jasné principy, které mají být součástí materiálního jádra, ale ani kritéria, podle kterých by se určily. ${ }^{10}$ Za druhé rozdělení ústavních norem na ustanovení tvořící „elitni“ „ohnisko“ a méně důležitý „,zbytek“", může mít neblahé praktické důsledky např. v poltickém boji či v konkrétní kauze. ${ }^{11}$

7 Viz např. bod 89 nálezu ÚS sp. zn Pl.ÚS 19/08 ve kterém je uvedeno výslovně: „Základním mèrítkem mu byl celý ústavni porádek, $i$ kdyžv jeho rámci stejnè brálo materiálmi ohnisko Ústavy - tedy podstatné nále ̌̌itosti demo-

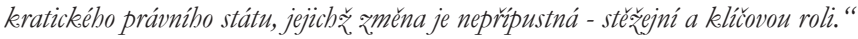

8 Viz např. HOLLÄNDER, Pavel. Materiální ohnisko ústavy a diskrece ústavodárce. Prámnike, č. 4, roč. 2005.

9 MOLEK, 2014, op. cit, s. 138.

10 Radoslav Procházka k tomu např. kriticky poznamenává, že ani odborníci se neshodnou, a proto je paradoxní, že by právě takováto matoucí kategorie měla sloužit jako bariéra pro výkon normotvorné působnosti té nejvyšší moci ve státě. PROCHÁZKA, Radoslav. Lud a sudcovia v konštitučnej demokracii. Plzeň: Vydavatelství a nakladatelství Aleš Čeněk, 2011, s. 32.

11 Např. Václav Pavlíček proto odmítá celý koncept „ohniska“ jako takový. Viz PAVLÍČEK, Václav. Kdo je v České republice ústavodárcem a problém suverenity. In: VANDUCHOVÁ, Marie, HOŘÁK, Jaromír (ed.). Na križovatkách práva: pocta Janu Musilovi ke sedmdesátým narozeninám. Vyd. 1. Praha: C. H. Beck, 2011, s. 22 . 
Každá ústava by však určitě měla vymezit, jak je určeno její území, kdo je jejím lidem a jak tento lid legitimuje státní moc. To je podle Pavla Molka oním „materiálním ohniskem“. ${ }^{12}$ Jak bylo nastíněno $\mathrm{v}$ úvodu, nelze zejména obecně ztotožňovat materiální jádro (ohnisko) s podstatnými náležitostmi demokratického právního státu či nezměnitelnými ustanoveními. Stát může být republikou či monarchií, federací či unitárním státem nebo může mít prezidentskou či parlamentní formu vlády. V̌̌dy to pro něj bude určující, bude to základ jeho ústavního systému. Nebude to však mít přímý vliv na to, zda se jedná o demokratický právní stát. To je mimoběžná kategorie.

Jednoduše řečeno, to zda je stát federací či unitárním státem sice určuje jeho naprosto základní charakter (identitu), neř́ká nám to však nic o jeho podstatě z hlediska demokratického právního státu. Pokud tedy změníme monarchii na republiku, změníme materiální jádro (ohnisko) její ústavy, nemusíme se však vůbec dotknout podstatných náležitostí demokratického právního státu.

Materiální jádro tedy můžeme vztáhnout spíše k ústavní identitě, tak jak ji chápe právo EU, jako např. v př́ipadě rozsudku ve věci C-208/09 Ilonka Sayn-Wittgenstein v. Landeshauptmann von Wien. ${ }^{13}$ Šlo o to, že Ilonka Sayn-Wittgenstein, rakouská občanka s bydlištěm v Německu, nabyla v návaznosti na své osvojení německým občanem Lotharem Fürst von Sayn-Wittgenstein jako rodné př́imení jméno se šlechtickým titulem ve formě „Fürstin (kněžna) von Sayn-Wittgenstein“. To ji nejprve bylo v Rakousku do matriky zapsáno, ale poté na základě rozhodnutí rakouského Ústavního soudu opět změněno na jméno „občanské“. Soudní dvůr v tomto ohledu uznal, že Unie ctí národní identitu svých členských států, jejî̌z součástí je rovněž republikánské státní zř́izení. ${ }^{14}$ Ústavní identita tak může být pojem trochu širší než pojem materiální jádro, resp. ohnisko ústavy, což už je to nejdůležitější z dané identity. Pokud by tedy Rakousko uznalo možnost zápisu šlechtických titulů do své matriky, je to zásah do republikánské identity, ale ještě ne nutně do materiálního jádra. Tím by bylo např. zavedení císařství. Vztah ústavní identity k materiálnímu jádru tak není nepodobný vztahu demokratického právního státu k podstatným náležitostem demokratického právního státu.

\section{Nezměnitelná ustanovení a „klauzule věčnosti“}

Nezměnitelná či „věčná“ ustanovení jsou jinou kategorií než materiální jádro či ohnisko ústavy. Jde o vyloučení změny či odstranění určitého principu, normy či hodnoty obsa-

12 MOLEK, 2014, op.cit, s. 196.

13 Rozsudek Soudního dvora (druhého senátu) ze dne 22. prosince 2010. Ilonka Sayn-Wittgenstein proti Landeshauptmann von Wien. Věc C-208/09. In: Sbirka roz̧hodnutí. 2010.

14 Gary Jacobson však ústavní identitu vnímá ještě trochu jinak, jako souhrn principů, od kterých by se psaná ústava neměla odchýlit, pokud chce zůstat $\mathrm{v}$ e společnosti stabilní. Viz k tomu JACOBSOHN, Gary J. Constitutional identity. Cambridge, Massachusetts: Harvard University Press, 2010. 
žené v ústavním systému daného státu. Typickým př́kladem takové klausule věčnosti je čl. 9. odst. 2 a 3 české Ústavy.

Nejstarší výslovná klauzule věčnosti byla vtělena do Ústavy švýcarské Helvétské republiky z roku 1798, která v poslední větě svého článku 2 stanovila: „Formou vlády, i kedyby méla býti żmènèna, musi nav̌̌dy zuistat zastupitelská demokracie. " ${ }^{15}$ Nicméně vzhledem $\mathrm{k}$ tomu, že byla sama Helvétská republika vytvořena $v$ důsledku francouzské invaze, není divu, že po čtyřech letech existence zanikla, a to i s ústavou, jejímž základním prvkem byla kromě „zastupitelské demokracie“ také centralizovaná vláda, tedy v obou prípadech pravý opak toho, čím je od počátku 19. století Švýcarsko charakteristické, tedy silným federalismem a neobvyklým podílem přímé demokracie (zejména právě na úrovni samosprávných kantonů). Pro budoucnost „klauzulí věčnosti“ v evropských ústavách to podle Pavla Molka nebyl právě povzbudivý př́klad. ${ }^{16}$

Nejstarší klauzuli „,věčnosti“ tak obsahuje druhá nejstarší dosud účinná konstituce. Jedná se o Norskou ústavu z roku 1814, která zapovídá změny svého ducha a svých principů (čl. 112). Roli ochránce však nesvěřuje soudům. Jak píše Eivind Smith, norská klauzule „věčnosti“ zajistila dlouhodobě hladký ústavní vývoj Norského království, určitě však nezajistila přetrvání původních principů a ducha původní mnohem více monarchistické ústavy. ${ }^{17}$ Je tedy důkazem selhání deklarovaného cíle, ale dosažení jiného bohulibého záměru. Možná by bylo vhodné ironicky poznamenat, že právě v tom tkví síla „nezměnitelnosti““.

Ve světě však lze nalézt př́kladů mnohem více. Některé z nich jsou pak velmi barvité. Např́klad Mexická ústava z roku 1924 stanovila, že náboženstvím mexického národa je a navždy bude Apoštolské rímské katolictví. Katarská ústava z roku 2004 chrání nedotknutelné postavení emíra. Několik nigerských ústav pak výslovně „zvěčňovalo“ amnestie pro pachatele zločinů proti lidskosti. ${ }^{18} 19$

Moderní klauzule věčnosti však čerpají z francouzské ústavní novely z roku 1884, která zakotvila jako nezměnitelnou republikánskou formu vlády a zejména z německého Základního zákona, podle jehož čl. 79 odst. 3 je nepřípustná taková změna, která se dotýká rozčlenění Spolku na země, zásadního spolupůsobení zemí při zákonodárství nebo zásad stanovených v článcích 1 a 20 Základního zákona (republikánské zř́izení a zásady

15 Za ještě starší předchůdce „klauzule věčnosti“ by se však daly označit některá ustanovení ústav amerických postkoloniálních států Delaware a New Jersey z roku 1776.

16 Viz MOLEK, 2014, op.cit, s. 35.

17 SMITH, Eivind. Old and protected? On the „Supra-constitutional“ clause in the Constitution of Norway. Israel Law Review. Roč. 44, vyd. 3., 2011.

18 Např́klad ústava Páté Nigerské republiky z 18. 7. 1999 ve svém článku 134 zapovídá mimo jiné jakoukoliv změnu posledního článku této ústavy, tedy článku 141. Tento článek pouze stanoví: Je udělena amnestie zosnovatelim pokusù o státní prevrat z.27. 1. 1996 a 9. 4. 1999.

19 Viz k tomu ROZNAI, Yaniv. Unconstitutional Constitutional Amendments — The Migration and Success of a Constitutional Idea. American Journal of Comparative Law. Roč. 61, vyd. 3, 2013. 
demokratického, sociálního a spolkového státu, suverenita lidu, dělba moci a vázanost moci zákonodárné ústavním řádem a moci výkonné a soudní zákony a právem). ${ }^{20}$ Např́klad slavná rozhodnutí Indického Nejvyššího osudu a celý další indický přístup $\mathrm{v}$ této věci je odvozen od myšlenek $\mathrm{z}$ německého vědeckého prostředí. ${ }^{2}$

V roce 2015 existovalo 193 platných a účinných psaných ústav. Z toho 59 obsahuje klasickou klauzuli věčnosti (30,6 \%) a 71 určitou formu klauzule omezující ústavní změny (36,8\%), 12 ústav pak obsahuje kombinaci těchto prvků (6,2\%). Pouze 51 Ústav nemá žádnou obdobnou formu omezení $(26,4 \%){ }^{22}$

$\mathrm{V}$ čem tedy tkví rozdíl mezi materiálním jádrem ústavy a jejími nezměnitelnými ustanoveními? Pomozme si metaforou Pavla Molka: „...pokud bychom si ústavu predstavili jako strédověké hrad, pak materiálni o hnisko prèdstavije jeji střed, jeji hlavni vě̌z, bez které celý hrad nebude dávat smysl a stane se obražným shlukem zbývajicich budov; oproti tomu nezmènitelné náležitosti jsou zesílenim bradebni zdi, které obvykle postavime tam, odkud prìsel minuly útok... Materiálni obnisko prìtom na rozdíl od nezmènitelných náležitosti vuibec nemusi mít ambici být věčné, naopak, dokéăže být fluidni a postupně se posouvat tak, jak se postupně posouvá viole lidu obledné základnich charakteristik. dané ústavy.“.23

Klauzule věčnosti je tedy spíše praktickým nástrojem, nikoliv podstatou systému. Je to vlastně nástroj obdobný jiným prostředkům zajišt'ující tuhost ústavy (např. kvalifikované většiny, potvrzující referendum atp.).

20 Obecně je často uváděno, že Základní zákon byl koncipován s ohledem na neúspěch Výmarské republiky (Např. EVERS, H.-U. Bonner Kommentar zum Grundgesetz. C. F. Müller, Art. 79 Abs. 3, Rn. 66.; HERDEGEN, M. In: MAUNZ, T., Dürig, G.: Grundgesetz. Band V., München, C. H. Beck, Art. 79, Rn. 63. Citováno podle: LAPČÁKOVÁ, Marta. Materiálne jadro základného zákona Spolkovej republiky Nemecko z pohl’adu Spolkového ústavného súdu. In: Ondrej Hamulák (ed.). Fenomén judikatury v právu. Olomouc: Leges, 2009, s. 114). Nicméně tato teze je do jisté míry problematická s ohledem na tzv. Radbruchův mýtus - tedy chybný závěr Gustava Radbrucha stran hodnocení neúspěchu Výmarské právní vědy a praxe (k tomu: SOBEK, Tomáš. Prámi myšleni: kritika moralismu. Praha: Ústav státu a práva AV ČR ve spolupráci s Vydavatelstvím a nakladatelstvím Aleš Čeněk, 2011, s. 370). Viz k tomu také BOBEK, Michal. Jak je důležité býti textualistou: o okouzlení hodnotovým výkladem práva a historické paměti středoevropského soudce. In: PŘIBÁŇ, Jiř́ a Pavel HOLLÄNDER. Právo a dobro v ústavní demokracii: polemické a kritické úvaby. Vyd. 1. Praha: Sociologické nakladatelství, 2011.

21 V únoru 1965 navštívil německý profesor Dietrich Conrad Indii a přednesl na právnické fakultě Hindské univerzity v Banarasu přednášku na téma „Implicitní omezení ústavních změn“. Přepis přednášky se dostal k rukám advokáta M. K. Nambyara, který zastupoval jednoho ze stěžovatelů v př́padě GolakNath (Předmětem sporu byla pravomoc parlamentu měnit Ústavu) a tak i před Nejvyšší soud. Yaniv Roznai danou přednášku cituje CONRAD, Dietrich. Limitation of Amendment Procedures and the ConstituentPower, I. Y.B.Int. Aff. (1966-1967). Viz ROZNAI, Yaniv. Unconstitutional Constitutional Amendments - The Migration and Success of a Constitutional Idea. American Journal of Comparative Law. Roč. 61, vyd. 3, 2013, s. 692.

22 Viz HEIN, Michael. Never say never. Katapult magazine, [on-line], [cit. 2016-6-21]. Dostupné z http:// katapult-magazin.de/en/artikel/article-katapult/fulltext/never-say-never/

23 MOLEK, 2014, op.cit, s. 138 a 141. 
Je na nás, resp. na ústavodárci, co si bude přát př́isněji chránit. Jen shodou okolností je v České republice tato ochrana pojata velmi široce a neurčitě, když se snaží „obrnit“ celé podstatné náležitosti demokratického právního státu.

\section{Podstatné náležitosti demokratického právního státu}

Podstatné náležitosti demokratického právního státu však také nelze obecně ztotožnit s nezměnitelnými ustaveními a ani s materiálním jádrem Ústavy.

Jde o abstraktní, neurčitý právní pojem, jehož jádro tvoří postupně (evolučně) vzniklý soubor základních vlastností demokratického právního státu, bez kterého by se již o takový stát nejednalo.

Je to tedy pojem obecně odlišný od pojmů vymezených výše. V českém prostředí je však často jak s materiálním jádrem ústavy, tak s jeho nezměnitelným náležitostmi nesprávně synonymicky zaměňován.

Velmi široce chápe podstatné náležitosti Pavel Holländer, když materiálním ohniskem v jeho systému není Ústava ani její části, ale hodnoty či principy na formulaci Ústavy v podstatě nezávislé. ${ }^{24}$ Komentář „ústavodárcư“ Dušana Hendrycha a Cyrila Svobody vymezuje podstatné náležitosti podstatně úžeji jako principy obsažené v čl. 1 odst. 1, čl. 5 a 6 Ústavy. ${ }^{25}$ Komentář Václava Pavlíčka a Jiř́ho Hřebejka jde jen trochu dále a podtrhuje ještě zejména suverenitu lidu zakotvenou v čl. 2 odst. 1 Ústavy. ${ }^{26}$

Mnoho dalších ústavních právníků se pokouší přesněji demokratický právní stát, resp. jeho podstatné náležitosti vymezit. Jakýmsi současným vyvrcholením tohoto úsilí je v úvodu zmiňovaná monografie Maxima Tomoszka, která se zabývá nejen samotným pojmem podstatných náležitostí demokratického právního státu, ale i demokratickým právním státem a principem „,rule of law“ jako takovými.

Pro Tomoszka podstatné náležitosti demokratického právního státu představují podmnožinu prvků spadajících do pojmu demokratického právního státu. ${ }^{27}$ Nejde však jen o sloučení principů demokracie a právního státu. Je založen na materiálním právním státu. $^{28}$

24 Viz SLÁDEČEK, Vladimír, Vladimír MIKULE a Jindřišsa SYLLOVÁ. Ústava České republikey: komentár. Vyd. 1. Praha: C. H. Beck, 2007, s. 72.

25 HENDRYCH, Dušan a Cyril SVOBODA. Ústava Ceské republikgy: komentár. 1. vyd. V Praze: C. H. Beck, 1997.

26 PAVLÍČEK, Václav a Jiří HŘEBEJK. Ústava a ústavní rád České republiky: komentár. 2. dopl. a roz. vyd. Praha: Linde, 1998.

27 TOMOSZEK, 2016, op.cit, s. 11.

28 TOMOSZEK, 2016, op.cit, s. 12. 
Vyčerpávající je podle něj vymezení podle čtyř základních principů: právní jistota, dělba moci, ochrana základních lidských práv a demokracie. ${ }^{29}$

Nejen doktrína se pokouší o bližší vymezení podstatných náležitostí demokratického právního státu. Ústavní soud ČR již sice několikrát pochopitelně odmítnul vytvářet přesný a úplný katalog či výčet náležitostí, které považuje za podstatné a jejichž změnu nehodlá prripustit. Přesto dal ve svých dřívějších nálezech návod jak jej chápat. Z nálezů sp. zn. Pl. ÚS $19 / 93^{30}$, sp. zn. III. ÚS 31/9731, sp. zn. Pl. ÚS 36/0132 a sp. zn. Pl.ÚS $19 / 08^{33}$ v zásadě vyplynulo, že ÚS chápe podstatné náležitosti demokratického právního státu materiálně a nikoliv formálně, že vnímá jako podstatné konkrétní právní principy, práva a demokratické hodnoty. Zdá se, že vưdčím principem Ústavy tedy jakousi hlavní „podstatnou náležitostí“ ${ }^{\text {v }}$ očích Ústavního soudu je priorita práv jednotlivce, ${ }^{34}$ tedy ochrana základních lidských práv člověka a občana zakotvená v tzv. „přirozenoprávních“ ustanoveních Listiny základních práv a svobod. ${ }^{35}$

Pokud bychom hledali nějaké shrnutí pojmu podstatných náležitostí demokratického právního státu v nálezech Ústavního soudu ČR, tak sám soud nám ho přináší ve svém prvním Lisabonském nálezu (sp. zn. Pl.ÚS 19/08 ze dne 26. 11. 2008), kde konstatuje, že „....jǐ̌v preambulich Listiny základnich práv a svobod a Ústavy vyjádril ústavodárce bezvýhradnou vázanost témito hodnotami, na nichž stoji nás konstitucionalismus; mj. uznal neporušitelnost prirozených práv člověkea, navazuje na obecnè sdílené hodnoty lidstvi a odhodláni chránit a rozvijet Ceskou republiku v duchu nedotknutelných hodnot lidské diistojnosti a svobody, spolu s villi, aby se zaradila mezi státy, které ty to hodnoty ctí, a to výslovnè jako součást rodiny evropských a svètových demokeracii. $Z$ blediska samotnébo textu Ústavy a Listiny základnich práv a svobod jsou v tomto smyslu klícové čl. 1 odst. 1 Ústavy a čl. 1 Listiny zák.ladnich práv a svobod, z nichž yyplývá, že Česká republika je surchovaný demokratický práuni stát založený na úctě ke nezadatelným, nezcizitelným, nepromlüitel-

29 TOMOSZEK, 2016, op.cit, s. 63.

30 Nález Ústavního soudu Čr ze dne 21. 12. 1993, sp. zn. Pl. ÚS 19/93. Ústavní soud ČR, [cit. 15. 6. 2016]. Dostupné z: http://nalus.usoud.cz/Search/Search.aspx

31 Nález Ústavního soudu ČR ze dne 29. 5. 1997, sp. zn. III. ÚS 31/97. Ústavní soud ČR, [cit. 15. 6. 2016]. Dostupné z: http://nalus.usoud.cz/Search/Search.aspx

32 Nález Ústavního soudu ČR ze dne 25. 6. 2002, sp. zn. Pl. ÚS 36/01. Ústavní soud ČR, [cit. 15. 6. 2016]. Dostupné z: http://nalus.usoud.cz/Search/Search.aspx

33 Nález Ústavního soudu ČR ze dne 26. 11. 2008, sp. zn. Pl.ÚS 19/08. Ústavní soud ČR, [cit. 15. 6. 2016]. Dostupné z: http://nalus.usoud.cz/Search/Search.aspx

34 Zajímavé je, že toto pojetí je v moderní psychologii často označováno za extrémní. Jonathan Haidt hovoři o tzv. WEIRD lidech (česky „divných“), tedy „Western“, „Educated“, „Industialized“, „Rich“ a „Democratic“ společenstvích, která mají zákonitě jinou představu o morálce, fungování společnosti a svých právech a povinnostech. Z hlediska historie lidstva se však tento individualismus jeví jako naprostá výjimka. Viz HAIDT, Jonathan. Morálka lidské mysli: proč lidstvo rozudéluje politika a náboženství. 1. vyd. Překlad Helena Čížková. Praha: Dybbuk, 2013, s. 332n.

35 Srovnej k tomu judikaturu Německého Ústavního soudu, který považuje za nejvyšší hodnotu Základního zákona lidskou důstojnost (viz explicitně v nálezu Ústavního soudu Německé spolkové republiky ze dne 10. května 1957, sp. zn. BVerfGE 6 (1957)). 
ným a nezrušitelným práviom a svobodám člověka, svobodnébo a rovnébo v diustojnosti a právech. Práva a svobody menšin obecnè $i$ z. národnostního či etnickébo blediska json prédmètem čl. 6 Ústavy (kde je stanovena povinnost dbát jejich ochrany), jakoži i hlavy tretí Listiny základních práv a svobod. Zákaz. diskriminace je zaručen zejména v čl. 3 Listiny základnich práv a svobod, princip pluralitni demokracie v jejím čl. 2 odst. 1, zásada solidarity predevšim v pasáži o hospodárských a sociálních právech Listiny základnich práv a svobod; sám politický systém je podle cl. 5 Ústavy založen na volné soutězu politických stran, odmitajicich násili jako prostredek k prosazováni svých zájmü a respektujicich základni demokratické principy. "

Je tedy zřejmé, že Ústavní soud ČR chápe podstatné náležitosti demokratického právního státu velmi extenzivně, když zmiňuje i sociální práva. Zároveň je však v chápání dvou prvních Ústavních soudů zřetelná koncepce obsahu tohoto pojmu. Tu lze vyjádřit dvěma postuláty. Prvním z nich je nadřazenost jednotlivce a jeho „přirozených“ práv. Druhou pak vláda práva, před kterou se musí sklonit i demokratická většina.

Bohužel však Ústavní soud ČR zejména vytváří dojem, že jsou podstatné náležitosti demokratického právního státu to samé, co materiální jádro ústavy a její nezměnitelná ustanovení.

Zde je tedy nutné znovu zopakovat, že nelze obecně tvrdit, že podstatné náležitosti demokratického právního státu splývají s kategorií nezměnitelných ustanovení. Některé Ústavy považují za nezměnitelnou formu státu (např. republika ve Francii či v Turecku), jiné své teritorium (např. Ukrajina), nebo konkrétní hodnoty dané ústavy (např. Německo, Rumunsko).

Navíc nám zde ještě „přebývá“ další kategorie, tedy qáklady demokratického státu dle čl. 9. odst. 3. Odlišovat „podstatné náležitosti demokratického právního státu“ a „základy demokratického státu“ nemá zatím zásadnější dopad na praxi a ani doktrínu. Jak však píše Pavel Molek, z konceptu „racionálního zákonodárce“ vyplývá, že pro totožné pojmy by neměla být používána odlišná slova. Podle Molka sice rozdíl existuje a čl. 9 odst. 2 vymezuje nezměnitelné náležitosti Ústavy, zatímco čl. 9 odst. 3 pak chrání její materiální ohnisko. ${ }^{36}$

Také Maxim Tomoszek si klade otázku, zda jde v tomto odlišení o omyl nebo nepozornost př́i psaní ústavy? Spíše je však podle něj pravděpodobnější, že jde o odlišné koncepty, a že jde o jakési prolnutí principů demokracie a demokratického právního státu. ${ }^{37}$ Můžeme z tohoto rozdílného pojmosloví také možná dovozovat i vzkaz interpretům Ústavy (v čele s Ústavním soudem ČR), aby dbali zejména na demokratický charakter státu. Praktické důsledky zde však nejsou dosud patrné a vytváří se spíše případný prostor pro nejasnosti.

\footnotetext{
36 MOLEK, 2014, op. cit, s. 147.

37 TOMOSZEK, 2016, op.cit, s. 45-46.
} 


\section{Hodnotová překážka neomezenosti moci, resp. „společné ohnisko ústav všech evropských států“}

Nejen Ústavní soud ČR chápe celou stavbu materiálního jádra ústavy, resp. klauzuli věčnosti jako součást širší konstrukci založené na univerzálním přirozenoprávním základě. Maxim Tomoszek hovoří o tzv. hodnotová překážce neomezenosti moci. Lidská práva náleží podle něj každému člověku z toho prostého důvodu, že je člověkem, tedy na základě lidství. Ani lid jako neomezený suverén nemůže přijmout rozhodnutí, kterým by např́iklad určité skupině obyvatel odebral jejich status člověka a tím je připravil o jejich základní práva. ${ }^{38}$

Pavlovi Molkovi se také zdá přesvědčivou teze o imanentnosti některých limitů, které váží ústavodárce (míněno i lid mimo ústavu) při přijímání ústavy. Některé limity majî podle něj totiž definiční povahu: už to, že má jít o „ústavu“, a to ústavu určitého státu, představuje limit daný samotnou definicí státu a definicí ústavy jako zpozitivnělé společenské smlouvy. ${ }^{39}$ Zde je vak skryta určitá nedotaženost či logická past. Molek tvrdí, že jsou zde patrně určité prvky, vlastnosti, danosti, které musí naplňovat každá ústava, má-li stát touto ústavou konstituovaný být hoden tvrdit, že „má vůbec ústavu““. ${ }^{0}$

Molek přímo píše: Jakekoli totiž neexistuje jasné univerzálni všude platné materiálni obnisko ústav, domnivám se, že lze analyzovat jednotlivé definični náležitosti, keteré musi ústava splňovat, aby byla (nároky budou v této enumeraci postupnè naristat) ústavou státu, aby byla ústavou odrážejici společenskou smlouvu, aby byla ústavou liberálnè demokratickon a aby byla ústavou „evropskou".41

Podle jeho názoru tedy i na ústavodárce, nejen ústavozákonodárce, určité limity dopadaji. Tvrdí tedy, že jsou určité prvky, které musí jakákoli nová - stejnè jako nynèjǔsi - ústava obsahovat, má-li být z. nynèjsìho pobledu hodna označeni ústava, že tedy existuje jakési „společné obnisko“ "prinejmenš̀m v'sech evropských (viz ní̌̌e) ústav. ${ }^{42}$

Existuje zde tedy „něco“, jakýsi předobraz Molkova hradu s výše uvedeného prŕikladu, který levituje v ř́ši idejí a který musíme následovat, jinak nepostavíme vůbec hrad (ústavu), ale patrně třeba vinici nebo pivovar. Pokud tedy tyto „společné“ principy nebudeme sledovat a dodržovat, octneme se místo v hradní věži (ústavě demokratického právního státu) ve sklepě pivovaru (patrně v ústavě autoritativního nedemokratického státu).

38 TOMOSZEK, 2016, op. cit, s. 101. Obdobně např. v poslední době souhrnně viz PEHE, Jiř́i. Lidská práva jako sekulární náboženství Západu. In: PŘIBÁŇ, Jiří, Petr AGHA, Václav BĚLOHRADSKÝ et al. Lidská práva: (ne)smysl české politiky? Praha: Sociologické nakladatelství (SLON), 2015. s. 51-63. ISBN 978-80-7419-230-2.

39 MOLEK, 2014, op.cit, s. 180.

40 MOLEK, 2014, op.cit, s. 181.

41 MOLEK, 2014, op.cit, s. 181.

42 MOLEK, 2014, op.cit, s. 181. 
Jakou však tedy má podstatu „společné ohnisko“ ústav všech evropských států“? Je to důležité i z hlediska výše provedeného dělení. Pokud totiž existují platónské ideje „prrirozených práv“, nutně tvoří podstatné náležitosti demokratického právního státu a nutně jsou i nezměnitelné. Člověk je jen objevuje, nevytváří a neničí. Taková představa je vlastní zejména německé doktríně. Patrně však nesnese srovnání s běžnou praxí.

Perez Zagorin k tomu uvádí, že prestože v současném světě existuje silné a vásnivé presvědčení sdílené mnoha běžnými lidmi, politickými aktivisty, intelektuály rĩzného drubu a rozmanitými filozofy, že každá lidská bytost je vybavena vrozenými právy, jejichž respektováni je morálně qávazné pro všechny osoby, autority a vlády, je pozoruhodným rysem literatury o tomto tématu, že neposkytuje žádný presvédčivý základ nebo dìkaz pro tvrzení, že taková práva skutečně existujį. ${ }^{43}$

Podobně je to se společným ohniskem evropských demokratických ústav, resp. s hodnotovou neomezeností státní moci, resp. dokonce moci samotného lidu. Lze jím argumentovat a využívat ho jak v politické diskuzi, tak v soudní argumentaci, patrně však nelevituje někde v říši idejí a dá se tedy i změnit a zneužít.

Nezbývá tedy než souhlasit s Tomášem Sobkem, že Radbruchova myšlenka, že lid si může demokraticky stanovit cokoliv, ale nic definitivně, je elegantním řešením paradoxu neomezené demokracie. ${ }^{44}$

\section{Závěr}

Tento článek je předložen s ambicí zpochybnit synonymnost pojmů materiálního ohniska a nezměnitelných náležitostí ústav (klauzule věčnosti), jakož i konceptu podstatných náležitostí demokratického právního státu a jakési další kategorie levitující v platónském světě idejí, kterou můžeme obecně označit za hodnotovou překážku neomezenosti moci, resp. „společné ohnisko ústav všech evropských států“.

Materiální jádro či ohnisko ústavy je základním charakteristickým prvkem daného systému. Tak jako sekt bez bublinek by stále byl vínem, nikoliv však sektem, tak i konkrétní ústava zbavená svého jádra bude úplně jinou ústavou.

To však neznamená, že ony „bublinky“ jsou podstatnými náležitostmi demokratického právního státu. Víno může mít mnoho podob a tedy i demokratický právní stát může být republikou či monarchií.

Aplikace těchto pojmů má zcela konkrétní důsledky pro ústavodárný proces, rozhodování Ústavního osudu, ale i další běžnou praxi. Je tedy potřeba je vymezit a poměrně jasně oddělit, ač v konkrétním prrípadě mohou splývat a překrývat se.

43 ZAGORIN, Perez. Hobbes and the law of nature. Princeton: Princeton University Press, 2009, s. 21.

44 SOBEK, 2011, op.cit, s. 411. Ostatně obdobně uvažoval již Jean Bodin, jen místo lidu dosazoval suveréna. 
Zejména „absolutní“ uvažování v pojmech jako je hodnotová překážka neomezenosti moci má zcela jasné důsledky pro užití klauzule věčnosti a petrifikování ústavního systému jako nezměnitelného výtvoru „prvni“" generace, ,jeffersonovské“ vlády mrtvých nad živými.

Proto je velmi žádoucí tento pojem „oddělit“ od pojmů jako jsou podstatné náležitosti demokratického právního státu nebo materiální jádro ústavy. 